\title{
Corporate Governance Attributes in Fraud Detterence
}

\author{
Raziah Bi Mohamed Sadique ${ }^{1}$, Aida Maria Ismail ${ }^{2}$, Jamal Roudaki ${ }^{3}$, Norhayati Alias ${ }^{2} \&$ Murray B. Clark $^{3}$ \\ ${ }^{1}$ Faculty of Accountancy, Universiti Teknology MARA, Negeri Sembilan, Malaysia \\ ${ }^{2}$ Faculty of Accountancy, Universiti Teknologi MARA, Selangor, Malaysia \\ ${ }^{3}$ Faculty of Commerce, Lincoln University, Christchurch, New Zealand \\ Correspondence: Aida Maria Ismail, Faculty of Accountancy, Universiti Teknologi MARA, Selangor, Malaysia.
}

Received: April 20, 2019

Accepted: May 7, 2019

Online Published: May 19, 2019

doi:10.5430/ijfr.v10n3p51

URL: https://doi.org/10.5430/ijfr.v10n3p51

\begin{abstract}
The failures of corporations such as Enron, WorldCom and HIH Insurance, to name but a few, have heightened investor awareness of the need to not only evaluate company performance, but also to consider the possibility that financial statements may not be a true reflection of company results, as fraudulent activities may have occurred during the reporting period. Since parties who are outside of the firm do not have access to pertinent information, they have to rely upon published financial and non-financial data to form an opinion regarding performance and/or the risk that fraudulent activities may have occurred. The prior literature shows a relationship between weak corporate governance and fraudulent activities, although most if not all of this research relates to Western economies. The differences in institutional setting e.g. cultural values and legal environment in Malaysia would not give the same findings with the study in western economies. Composing of many ethnicities, Malaysia is a multicultural country. With each ethnic group upholding its own culture, values and belief, businesses are conducted according to each ethnic's culture. The results of this study could shed some light on the influence of institutional setting regarding corporate governance. Companies that were charged with accounting and auditing offences from year 2003 to 2007 were selected as the fraudulent samples. Data was collected from the years these companies were charged with fraud and the year prior to that. Logistic regression analysis was carried out to determine the significant differences between fraudulent and non-fraudulent companies with respect to corporate governance characteristics. The results indicated that the size of the board and the percentage of institutional shareholdings had significant relationships with the likelihood of corporate fraud occurrences consistently across the two-year period studied. The results of this study will assist public, corporate and accounting policy makers in formulating more effective corporate governance mechanisms.
\end{abstract}

Keywords: corporate fraud, fraud, economic crime, corporate governance

\section{Introduction}

A survey conducted by PwC's (2018) highlighted that fraud and corruption remain pervasive in businesses. In addition to financial losses, the survey described non-financial losses resulting from corporate fraud, including damage to companies' brands or goodwill, loss of employee morale, damage to business relations with outside parties (especially regulators) and decreases in the value of companies' shares. The repercussions of corporate fraud affect not only the companies and their shareholders, but also employment, social stability and the public at large. The reverberations of corporate fraud can be clearly seen in the cases of Enron, Worldcom, Parmalat and many others. Among those that suffer from corporate fraud are those that rely on published information to assess company performance and make investment decisions, such as stockholders and the general public. The serious consequences of corporate fraud have prompted strong control and monitoring mechanisms to be enacted, with the goal of overseeing corporate and management activities.

The separation of control and ownership increases the need for effective monitoring and control over management to protect the interests of investors and stakeholders (Fama and Jensen, 1983. Investor and stakeholder interests are usually protected using a three-tier system (Ramaswary, 2005). The first tier is the company's code of corporate governance; among others, the objectives of the code are to ensure that company policies are enforced, goals are met, performance is monitored and disclosures of company activities are adequate. The second tier is the company's internal control system. Here the objectives are to provide reasonable assurance of the effectiveness and efficiency of company operations, the reliability of financial reporting, and compliance with laws and regulations. The third tier is 
the regulators (e.g. the Securities Commission). Regulators are responsible for overseeing the company's reporting system and ensuring compliance with disclosure standards, auditing standards, procedures and independence, ethical standards, and quality control standards.

Debates on the integrity of financial reporting have broken out as the number of reported corporate bankruptcy and fraud cases increases (Rezaee, 2005). This has become an issue that concerns regulators as well as users of financial reports (AICPA, 1993; Treadway Commission, 1999). Deficiencies in internal controls resulting from weaknesses in corporate governance structures have contributed to the increase in fraudulent activities (Beasley, 1996; Riahi-Belkaoui and Picur, 2000). The pressure to maintain the company's performance can become the motivation for managers to manipulate financial reports (Ramaswary, 2005). Riahi-Belkaoui and Picur (2000) indicated that management's ability to override internal controls is another contributing factor to fraud. As concerns about fraud increases, companies are being urged to fortify their internal control systems by strengthening their corporate governance.

The main focus of this study is to evaluate the effectiveness of corporate governance lowering the risk of fraud. Information published is vast and at times it is too technical for the general users to understand and evaluate the impact on future performance. Therefore, it is impossible to study and analyze all of the information presented in the published report. The selection of corporate governance information is due to the role of governance in monitoring and controlling business activities. Thus, good and effective governance means good control and monitoring over business activities which is extended towards lowering the risk or likelihood of corporate fraud. In order to distinguish between healthy and unhealthy practices of corporate governance, a control group (healthy companies) will also be studied (this data became the 'benchmark' of healthy practices). Both groups' data were empirically tested and regressed; to determine the significant relationship between the practices and the likelihood of corporate fraud occurrences.

\section{Literature Review}

The need for an effective corporate governance system in companies is undeniable. Reference (Cullinan and Sutton, 2002) found that $70 \%$ of the fraud in companies involved CEOs and $20 \%$ involved senior managers. Reference (Bell and Carcello, 2000)found that the significant risk factors of fraud included a weak internal control environment; rapid company growth; inconsistent or inadequate probability; an undue management focus on meeting earnings projections; an overly evasive or lying management; private ownership status; and an interaction factor between weak controls and aggressive management attitude towards financial accounting. Beasley (1996) study on fraud risk factors found that non-fraudulent firms have significantly higher percentages of outside members than fraudulent firms. A study by Grove and Basilico (2008) focused on fraudulent financial reporting detection had concluded that an all-powerful CEO, weak system of management control, senior management turnover, insider stock trading and questionable business strategies with opaque disclosure are significant red flags for fraudulent companies. Reference (Grove and Cook, 2004) arrived at the same conclusion in their analysis of the financial statements of Enron, WorldCom, Qwest and Global Crossing. Some of the red flags are corporate culture, a lack of internal controls and problems with companies' auditors in terms of high consultation fees as compared to audit fees. (Beasley, et al, 2000; Beasley, et al, 2000) also found that a weak governance system is associated with fraud occurrences.

The board of directors has been identified as one of the important ways to control managers' actions (Fama, 1980). A higher number of independent board members have helped in reducing the incentives for earnings in management, which resulted in better control (Baysinger and Hoskisson, 1990; Borokhovich, et al, 1996; Jensen, 1993). (Jensen, 1993; Lipton and Lorsch, 1992) found that a board with a higher percentage of independent directors will provide better decision control and monitoring of management activities. Petra (2005) found that external and independent directors do strengthen corporate governance. Meanwhile, Saksena (2003) found that more independent directors on the board significantly reduced the likelihood of financial statement fraud. Carcello and Nagy, (2004) found that non-fraudulent companies have a higher proportion of external directors than fraudulent companies, and this is consistent with the findings of Beasley (1996). In examining the relationship between the credibility of financial reporting systems and the quality of corporate governance, Farber (2005) found that the fraudulent companies showed weak governance as compared to control firms. In particular, fraudulent companies had a smaller number of external board members and audit committee meetings, a small percentage of 'Big 4' auditing firms, and a higher percentage of CEO duality.

Chen et al, (2006) found that in China, CEO duality is not a significant fraud deterrent. Saksena (2003) discovered that CEO duality is positively significant with management fraud; the existence of a dual role on the board increases the CEO's power over the board, increasing the likelihood of fraud. This is consistent with the study conducted by Bliss et al, (2011) in Australia, which indicated that dual roles reduced the effectiveness of the board's independence in 
carrying out their responsibilities. Kim et al, (2009) in their study on the relationship between CEO duality and corporate diversification in the US, stated that there is a positive relationship between duality and unrelated corporate diversification. Haniffa and Hudaib, (2006) established that duality is negatively related to company performance, and this supports the argument that if the CEO has too much power in decision making, they may end up pursuing their own interests (Jensen, 1986). This finding is consistent with Dey et al, (2011) discovery that compensation pay for CEO's with a dual role is significantly higher compared to CEOs without a dual role. An established CEO, that is, a CEO who has been on the board for a long time, will be more effective in influencing the board when compared to a new CEO (Hermalin, 2005; Hermalin and Weisbach, 1988). A CEO with a dual role and a long tenure has been found to have more influence over the board (Kim et al, 2009). In a study on the impact of board composition and ethnicity on audit quality in Malaysia by Salleh et al, (2016) the researchers found that board independence promoted the appointment of a higher quality of auditors which indicated better assurance of audit quality. Malaysia is a multicultural country, composed of many different ethnicities, which include Malays, Chinese and Indians. Every ethnicity has its own unique cultural values and beliefs. Studies on culture have found that differences in cultural practices have influences over business practices, organizational structure, managerial style, accounting disclosure practices, auditing services and governance structures Claessens et al, 2000; Haniffa and Cooke, 2002; Hofstede, 1980; Yatim et al, 2006). As indicated by Hofstede (1980) culture determines institutional practices and how they are formed.

A study by Mohd Salleh and Othman, (2016) on boards attributes as deterrence to corporate fraud in Malaysia; found that the frequencies of board meetings could be used to monitor the company. The study indicated that the more frequent the board meets, the better control will be over the company activities. The study also found that the size of board and duality is not significant in fraud deterrence. Abdullah et al, (2010) study on financial restatement and corporate governance in Malaysia indicated that board independent, audit committee independent, managerial ownership and CEO duality did not have significant effect on the likelihood of financial misstatement. The study found that the higher percentage of institutional ownership reduces the event of financial misstatement. Malaysian companies are highly concentrated since the majority of companies in Malaysia are family-owned and having outsiders holding ownership could increase control and monitoring of these companies activities.

For a board to effectively control and monitor managers, the number of board directors should be seven or eight Lipton and Lorsch, 1992; Petra, 2005). The smaller the number of directors on the board (fewer than 10) the more effective the board is at carrying out their function (Yermack, 1996). Chen et al, (2006) studied corporate fraud in China and found that board size is not significant in deterring fraud; this is consistent with (Uzun et al, 2004; Carcello and Nagy, 2004; Farber, 2005; Bradbury et al, 2006; Smaili and Labelle, 2009). However, Beasley, (1996) found that a larger board increased the likelihood of financial statement fraud as it reduced the effectiveness of the controls. Xie et al, (2003) on the other hand, found that having a larger board is associated with fewer earnings in management activities. The importance of frequent board meetings is highlighted in the Malaysia Code of Corporate Governance best practices. The Code suggests the board should meet regularly, at least four times per year. The more frequently the board meets the more effective it will be at monitoring and controlling management activities (Abbott et al, 2004; He et al, 2009; Lipton and Lorsch, 1992). Having frequent meetings means that the directors will review the company's activities more often and will be kept updated on the company's performance. A study by Chen et al, (2006) in China found that more frequent board meetings reduced the likelihood of fraud occurring. This indicates that effective monitoring and controlling of management activities will reduce the likelihood of fraud activities. In contrast, (Jensen, 1993; Smaili and Labelle, 2009; Bédard et al, 2004) found that the frequency of board meetings does not necessarily lead to effective monitoring of management.

Owens-Jackson et al, (2009) analysed the relationship between audit committee characteristics and fraudulent financial reporting and found that independence and the number of audit committee meetings are negatively related to the likelihood of fraudulent financial reporting. Ferris et al, (2003) analysed the monitoring performance of directors with multiple board appointments found that multiple directorship did not reduce the effectiveness of audit committees in performing their monitoring responsibilities (consistent with Fama and Jensen (1983)). Another study on multiple directorship and firm performance in India indicated that members with multiple directorships have a positive effect on firm's value and they attend more meetings (Sarkar and Sarkar, 2009; Schnake and Williams, 2008) indicated that holding a multiple directorship and serving on a larger board diminished the focus of the directors in their monitoring responsibilities as larger boards are more difficult to coordinate. Sharma and Iselin (2012) study on the association of audit committee directorship and tenure with the financial statement occurrences found that having multiple directorship increases the occurrences of financial misstatements since their findings suggested that multiple directorship reduced the effectiveness in monitoring companies. This finding is consistent with the study by Tanyi and 
Smith (2014) that the busyness of audit committee members weakens the monitoring performance. Burns (2003) found that large block holders are able to monitor effectively and can have an influence over the company's corporate governance practices that will reduce the likelihood of fraud. Similarly, Bushee (2000) found that when companies have high institutional stockholdings, it increased the firms' value in their long-term earnings. Kim et al, (2009) found that a higher concentration of institutional shareholdings in a company led to better monitoring and control of the company's activities (unrelated corporate diversification), in particular regarding a dual CEO.

\section{Research Methodlogy}

As the objective of this study is to determine the usefulness of corporate-published information in indicating if a company is at risk of fraud, the selection of fraudulent companies and non-fraudulent companies was vital. The general criteria for both groups of companies are as follows:

i. Companies were selected from public listed companies in Bursa Malaysia.

ii. Banking, finance, insurance and unit trust companies were excluded.

iii. All companies for both groups needed a complete set of data for each year analyzed; therefore, companies with incomplete data were excluded.

Fraudulent companies were selected from Malaysia Securities Commission Enforcement Release that was charged with accounting and auditing offences from 2003 to 2007. The reason for starting the selection in 2003 was because the Malaysian Code of Corporate Governance was introduced in 2000, while 2001 was considered an adjustment period year for companies to adapt to the new requirements. Thus, the year 2002 was appropriately decided as the starting year for data collection, and since the data on corporate governance for this study covered two years (the fraud year and the year prior to the fraud year), the selection of fraudulent companies started from 2003. The Code was revised on 1st October, 2007, and in 2008, the global recession began to take effect; therefore, the cut-off period for the selection of fraudulent companies for this study was 2007.

The non-fraudulent companies that are the control companies in this research were selected from public listed companies on Bursa Malaysia. The companies were selected based on their similarity to the fraudulent companies in time period, industry type and size. The non-fraudulent companies must not have any record of being investigated for commercial crime either by the Securities Commission or any other regulatory bodies or in financial distress (not listed in the PN4 or PN17 listing). Distressed companies were excluded because of the statement made by Malaysian Securities Commission that many of the losses suffered by PN4 and PN17 companies are caused by mismanagement, fraud and other unethical practices (Anwar, 2006).

The Malaysia Securities Commission Enforcement Release (MSCER) disclosed 84 fraud cases (from 2003 to 2007). Out of this total, 34 companies were involved and charged with accounting and auditing offences by the Malaysia Securities Commission. From the 34 companies, 13 are no longer trading (bankrupt or liquidated). A final sample of 11 companies was used for this study as the other 10 companies either did not have complete sets of data or were not public companies. Private companies are not required to publish annual reports and therefore, were excluded from this study. Out of the 11 companies selected, five were charged in 2007, two in 2005, one in 2004 and three in 2003. None of the companies charged in 2006 were selected for this study as they did not meet the necessary criteria. The year when the company was charged and listed in the MSCER is referred to as the first year of fraud or year t. The selection of non-fraudulent companies was based on the fraudulent companies. As explained earlier, the selection of non-fraudulent companies was bound to the criteria mentioned. A final sample of 149 non-fraudulent companies and 11 fraudulent companies was used for this study.

\subsection{Data and Data Analysis}

The corporate governance characteristics or variables were obtained from companies' corporate governance reports, director profiles and analyses of shareholdings. The corporate governance characteristics analysed in this study are divided into four areas. The first area is characteristics of the board of directors, namely: independence of board (INBOD), total number of board members (TBOD), number of board meetings (BODMEET) and percentage of director shareholdings in the company (DIROWN). Second area is the characteristics of the board's chairman, namely: duality (DUALITY), chairman's ethnicity (ETHNIC) and chairman's tenure (TENURE). The next corporate governance variables are the audit committee characteristics which include the independence of the audit committee members (INDAC), the proportion of audit committee members having at least one additional directorship in another company to total number of audit committee member (OUTDIR) and the frequency of audit committee meetings (ACMEET). The last area is the percentage of institutional shareholdings or block holder stock ownership (BLOCK). 
Both the descriptive analysis and logistic regression analysis were carried out. To determine the multivariate relationships between the corporate governance characteristics and corporate fraud, this hypothesis is tested:

Ho: There is no significant relationship between the corporate governance characteristics with the likelihood of corporate fraud.

In order to test the hypothesis, logistic cross-sectional regression analysis was carried out using the proposed model (consistent with Beasley, 1996; Uzun et al, 2004; Persons, 2005):

$$
\begin{aligned}
\text { FRAUD }_{i} & =\alpha+\beta_{1} \text { INDBOD }_{i}+\beta_{2} \text { DUALITY } \beta_{3} \text { TENURE }_{i}+\beta_{4} \text { BODMEET }_{i} \\
& +\beta_{5} \text { TBOD }_{i}+\beta_{6} \text { ETHNIC }_{i}+\beta_{7} \text { DIROWN }_{i}+\beta_{8} \text { INDAC }_{i} \\
& +\beta_{9} \text { OUTDIR }_{i}+\beta_{10} \text { ACMEET }_{i}+\beta_{11} \text { BLOCK }_{i}+\varepsilon_{i}
\end{aligned}
$$

Where:

FRAUD $=$ A dummy variable with a value of 1 when a firm is alleged to have experienced financial statement fraud and a value of 0 or otherwise.

INDBOD = The percentage of board members who are not the companies' Managing Directors' (not currently officers or employees of the companies).

DUALITY $=$ The CEO is also the chairman of the board.

TENURE $=$ The number of years the chairman has served as a director.

BODMEET $=$ The frequency or number of board meetings in a year.

$\mathrm{TBOD}=$ The number of members on the board.

ETHNIC $=$ The chairman's ethnicity; Malay or others.

DIROWN $=$ The percentage of manager (insider) ownership of company shares.

INDAC $=$ The proportion of independent audit committee members to total number of audit committee members .

OUTDIR $=$ The proportion of audit committee member having at least one additional directorship in another company to total number of members.

ACMEET $=$ The number of audit committee meetings held in a year.

BLOCK $=$ The percentage of block holders (institutional) who owns more than $5 \%$ of shares in the company (direct shareholdings).

$I=$ The firms.

$\varepsilon=$ The residual.

$\beta=$ The slope coefficient.

\section{Discussion of Results}

Table 1. Logistic regression estimation of likelihood of corporate fraud occurences for both years

\begin{tabular}{lllllll}
\hline \multirow{2}{*}{ Variables } & Year $\boldsymbol{t}$ & \multicolumn{5}{c}{ Year $\boldsymbol{t}$-1 } \\
\cline { 2 - 7 } & $B($ sign $)$ & $\begin{array}{l}\text { Exp } B(\text { Odds } \\
\text { ratio })\end{array}$ & $p$ & $B($ sign $)$ & $\begin{array}{l}\text { Exp } B(\text { Odds } \\
\text { ratio })\end{array}$ & $p$ \\
\hline INBOD & -0.062 & 0.940 & 0.276 & -0.053 & 0.949 & 0.294 \\
\hline TBOD & -0.784 & 0.457 & $0.024 * *$ & -0.608 & 0.544 & $0.065^{*}$ \\
\hline BODMEET & 1.045 & 2.842 & $0.038^{* *}$ & 0.403 & 1.496 & 0.105 \\
\hline DIROWN & -0.049 & 0.952 & 0.171 & -0.078 & 0.925 & $0.027^{* *}$ \\
\hline DUALITY & -0.391 & 0.676 & 0.716 & 1.387 & 4.003 & 0.274 \\
\hline
\end{tabular}




\begin{tabular}{lllllll}
\hline TENURE & -0.254 & 0.776 & $0.080^{*}$ & -0.050 & 0.951 & 0.308 \\
\hline ETHNIC & 1.458 & 4.296 & 0.175 & 1.936 & 6.931 & $0.075^{*}$ \\
\hline INDAC & 0.004 & 1.004 & 0.916 & 0.002 & 1.002 & 0.973 \\
\hline OUTDIR & -0.017 & 0.983 & 0.341 & 0.002 & 1.003 & 0.836 \\
\hline ACMEET & -0.598 & 0.550 & 0.194 & -1.049 & 0.350 & 0.110 \\
\hline BLOCK & -0.078 & 0.925 & $0.009^{* * *}$ & -0.093 & 0.911 & $0.003^{* * *}$ \\
\hline CONSTANT & 5.407 & 4.349 & 0.214 & 9.804 & 5.649 & 0.83
\end{tabular}

a. Variable(s) entered at step 1: INBOD, TBOD, BODMEET, DIROWN, DUALITY, TENURE, ETHNIC, INDAC, OUTDIR, ACMEET, BLOCK

$*, * *, * * *$ denote significances at $10 \%, 5 \%$ and $1 \%$, respectively.

To determine the relationships between the corporate governance variables and the likelihood of corporate fraud occurrences, hypothesis testing of relationships was carried out using logistic regression analysis and the result is presented in Table 1. Only four of the variables were significant predictors of the likelihood of corporate fraud for year's $t$ and $t-1$. The significant predictors for year $t$ were: size of board, number of board meetings, chairman's tenure and percentage of institutional shareholdings. The significant predictors for year $t-l$ were: size of board, percentage of directors' shareholdings, chairman's ethnicity and percentage of institutional shareholdings. However, only size of board and percentage of institutional shareholdings were found to be constantly significant predictors of the likelihood of corporate fraud for the two years studied.

Analysis of the independence of the board of directors (INBOD) for both years evidenced that this factor is not a significant contributor to the effectiveness of corporate governance in fraud deterrence, as shown in both the univariate and logistic regression analyses. This suggests that independent board directors do not reduce the likelihood of fraud occurrences. The Bursa Malaysia Listing Requirement (Paragraph 15.02) requires companies to have at least two directors, or $1 / 3$, on the board that are independent (whichever is higher). Upon investigation of this variable, the mean INBOD for both groups of companies were above the required percentage, showing that compliance with the requirement by both groups of companies was high. This result is consistent with the findings of Hasnan et al, (2008) on fraudulent financial reporting in Malaysia. Other studies on the role of board independence with respect to its effectiveness in monitoring company activities and performance in a Malaysian setting also found that the independence of board member is not significant (Anwar, 2006; Smaili and Labelle, 2009; Hashim and Devi, 2008; Li and Ang, 2000). On the other hand, this result is in contrast with (Beasley, 1996; Xie, et al, 2003; Lipton and Lorsch, 1992) who found that the higher the percentage of independent board members, the better the control. However, these studies were not conducted in Malaysia. This study shows that on average the percentage of independent board members is $37 \%$ to $43 \%$, which is above the required percentage. Therefore, null hypothesis $1 \mathrm{~b}$ is accepted for both years, indicating that INBOD is not a significant predictor of the likelihood of corporate fraud. This result highlights the ineffectiveness of INBOD at monitoring and controlling company activities and reporting. Perhaps a more in-depth study could be carried out to examine this variable in order to understand why it is weak; is it due to the number of independent members or the members themselves not being competent in carrying out their duties? Perhaps the suggestion by Ahrens et al, (2011) to look beyond directors' independence could be further investigated, e.g. the competency of the directors in terms of knowledge and experience could be studied.

For year $t$, size of the board (TBOD) was a significant predictor variable in the logistic regression results. TBOD was significant at the 5\% significance level, with a $p$ value of 0.024 . The result indicated a negative $B$ value of -0.784 , which means that an increase in the number of board members reduces the likelihood of fraud occurring. The odds ratio (0.457) was less than 1 , so for every additional person on the board, fraud will be 0.457 times less likely to occur, controlling other factors in the model. The non-fraudulent companies had a higher number of members on their boards than the fraudulent ones. The results indicated that a higher number of members on the board reduced the likelihood of corporate fraud. The size of the board (TBOD) was also a significant predictor in the logistic regression result for year $t-1$. TBOD was significant at the $10 \%$ significance level, with a $p$ value of 0.065 . The result showed a negative $B$ value of -0.065 , which means that an increase in the number of board members reduces the likelihood of fraud occurrences. The odds ratio (0.544) was less than 1, indicating that for every additional person on the board, fraud will be 0.544 time less likely to occur, controlling other factors in the model. This result shows that having at least eight members on the board could influence (reduce) the likelihood of corporate fraud. The effectiveness of a TBOD of at least eight members in this study is consistent with the suggestion by (Jensen, 1993; Lipton and Lorsch, 1992). Beasley (1996) 
found that a larger-sized board increased the likelihood of fraud. This result is consistent with the findings of Hasnan et al, (2008) as well as the recommendation of the Malaysia Code of Corporate Governance 2011 Blueprint. The findings of Beasley (1996) are in contrast with the result of this study, which found that on average, fraudulent companies have a lower number of board members than non-fraudulent companies, suggesting that a larger board is more effective at reducing the likelihood of fraud. So, it can be said that in a different cultural and legal environment (e.g. Malaysia), more members on the board increases the effectiveness of a company's governance and as a result, reduces the likelihood of corporate fraud. Therefore, null hypothesis is rejected for both years; as there is a significant relationship between size of board and the likelihood of corporate fraud in Malaysia.

For year $t$, the number of board meetings in a year (BODMEET) was also a significant predictor; therefore, null hypothesis is rejected. The results showed that there is a significant relationship between the frequency of board meetings and the likelihood of corporate fraud occurrences. BODMEET was significant at the 5\% significance level, with a $p$ value of 0.038 . There was a positive B value of 1.045 , which means that frequent board meetings are unlikely to reduce the likelihood of fraud. The odds ratio (2.842) was more than 1 , so for every additional board meeting, fraud will be 2.842 times more likely to occur, controlling other factors in the model. While frequent board meetings may not reduce the likelihood of corporate fraud, this factor could possibly highlight that a company is in distress and at risk of fraud. This result is consistent with (Uzun et al, 2004; Bédard et al, 2004) who found that frequent board meetings do not necessarily lead to effective monitoring and control. However, BODMEET was found not to be significant in year $t-1$ and therefore for year $t-1$ null hypothesis is accepted. One possible reason for this inconsistent result is that the average number of board meetings in year $t-l$ was six for fraudulent companies and five for non-fraudulent companies, so there was a minor difference between the groups.

Directors' shareholding (DIROWN) was not a significant contributor to reducing the likelihood of corporate fraud for year $t$. This indicates that the percentage of directors' shareholdings did not reduce the likelihood of fraud in year $t$; therefore, null hypothesis is accepted. Directors' shareholdings (DIROWN) appeared to be a significant predictor in the regression model for year $t-1$. DIROWN was significant at the $5 \%$ level, with a $p$ value of 0.027 . There was a negative $B$ value of -0.078 , meaning an increase in the percentage of directors' shareholdings reducing the likelihood of fraud. The odds ratio $(0.925)$ of less than 1 indicated that for every additional $1 \%$ of directors' shareholding, fraud will be 0.925 times less likely to occur. This result is in contrast with the findings of Owens-Jackson et al, (2009). For both groups of companies, on average about $10 \%$ of directors held shares in the company, which is relatively low. The average directors' shareholding for fraudulent companies in year $t$ was $9 \%$, and for non-fraudulent companies it was $11 \%$. One possible explanation for this predictor being significant in year $t-1$ is that having $10 \%$ or more directors' shareholding could reduce the likelihood of corporate fraud occurrences. Therefore, for year $t-1$ null hypothesis not supported.

Chairman's duality (DUALITY) was not a significant contributor to the weaknesses of corporate governance in fraud deterrence, as shown in the logistic regression analyses for both years studied. This implies that the chairman's dual role does not increase the likelihood of fraud. This result is consistent with the findings of Chen et al, (2006). Upon investigation of DUALITY in both groups, only $16 \%$ and $16 \%$ respectively of the non-fraudulent companies, and $18 \%$ and 9\% respectively of fraudulent companies had a CEO who was also the board chairman for year's $t$ and $t-1$. This shows that there was a low percentage of DUALITY in both groups of companies and the separation of CEO and chairman did not reduce the likelihood of corporate fraud. Therefore, null hypothesis is accepted for both years. Even though Bursa Malaysia does not make it mandatory to separate the roles of board chairman and CEO, the majority of the companies in both groups did not have dual roles. Since this practice was somewhat the same in both groups, it could be the reason why no significant relationship was found. This could also indicate that the separation of board chairman and CEO is not effective in reducing the likelihood of corporate fraud in Malaysia. Perhaps having the CEO as the board chairman increases the governance over the company's activities and reporting due to the knowledge and experience that the CEO has of the company.

The results for year $t$ indicated that chairman's tenure (TENURE) was another significant predictor variable in the logistic regression, but it was not a significant predictor for year $t-1$. Therefore, null hypothesis is rejected for year $t$ and accepted for year $t-1$. TENURE was significant (at the $10 \%$ significance level), with a $p$ value of 0.080 . The result gave a negative $B$ value of -0.254 , which means that an increase in chairman's tenure reduces the likelihood of fraud occurrences. The odds ratio (0.776) was less than 1, indicating that for every additional year the chairman is on the board, fraud is 0.776 time less likely to occur, controlling the other factors in the model. The mean rank of chairman's tenure for the non-fraudulent companies was higher than for the fraudulent companies, which could indicate that longer chairman's tenure may possibly reduce the likelihood of corporate fraud. The longer the tenure of the chairman, the more knowledge and experience they have, which could contribute to reducing the likelihood of corporate fraud. 
Also, these chairmen are reluctant to take risks that could destroy their reputations, such as unlawful activities. This result is consistent with the findings of (Chen, et al, 2006; Hill and Phan, 1991).

Chairman's ethnicity (ETHNIC) was also not a significant contributor to the effectiveness of corporate governance in fraud deterrence, as shown in logistic regression analyses for year $t$; therefore, null hypothesis is accepted. This shows that the chairman's ethnicity did not contribute to the likelihood of fraud occurrences. However, this variable was a significant predictor for year $t$ - 1 . ETHNIC was a significant predictor in the regression model. ETHNIC was significant at the $10 \%$ significance level, with a $p$ value of 0.075 . The result gave a positive $B$ value of 1.936 , which means an increase in non-Malay chairmen increases the likelihood of fraud. The odds ratio (6.931) was more than 1, indicating that having a non-Malay chairman increased the likelihood of corporate fraud occurrences by 6.931 times in year $t-1$. For year $t-1$, null hypothesis is rejected, suggesting there is a significant relationship between the chairman's ethnicity and the likelihood of corporate fraud occurrences. The inconsistency in the results between the two years may be due to changes in board chairmen, as in year $t-1$ only two Malay chairmen were recorded in the fraudulent sample, which increased to three in year $t$. This variable needs to be further examined to include cultural factors and practices that could contribute to the effectiveness of having more Malay chairmen.

Percentage of independent audit committee members (INDAC) was not a significant contributor to the effectiveness of corporate governance in fraud deterrence, as shown in logistic regression analyses for both years. Therefore, null hypothesis is accepted for both years, which means that there is no significant relationship between the percentage of independent audit committee members and the likelihood of corporate fraud. This indicates that the percentage of independent audit committee members will not reduce the likelihood of fraud and is consistent with the result for INBOD. An investigation into this variable showed that all of the companies complied with the minimum requirements of Bursa Malaysia. Independence of audit committee members ranged between $72 \%$ and $74 \%$; while the minimum requirement is $66.67 \%$. This could suggest that the minimum requirement is not effective in fraud deterrence. Perhaps the minimum number of audit committee members needs to be increased, as more members could increase the effectiveness of its role in governance, as can be seen from the size of the board.

The number of audit committee meetings in a year (ACMEET) was not a significant contributor to the effectiveness of corporate governance in fraud deterrence, as shown by the logistic regression analyses for both years. This means that more audit committee meetings do not reduce the likelihood of fraud. An increase in audit committee meetings could possibly indicate that companies are in trouble. The Listing Requirement calls for audit committees to have at least four meetings a year. Both groups complied with this requirement; on average five to six meetings were held per year. Could it be this number of meetings is not sufficient for properly discussing and analysing financial reports? Or perhaps the meetings are not set up to critically assess financial matters? An in-depth analysis of this variable could help in understanding the effect of the meetings and how to improve their effectiveness. The results for INDAC and ACMEET are not consistent with the findings of (Abbott et al, 2000; Uzun, et al, 2004; Owens-Jackson, et al, 2009) who found a significant negative relationship between INDAC and ACMEET and the likelihood of fraud. Again, differences in culture and legal environment could contribute to the inconsistency between the results of this study and the studies mentioned above.

Outside directorships held by audit committee members (OUTDIR) were also found to be not a significant contributor to the effectiveness of corporate governance in fraud deterrence, as shown in the logistic regression analysis. Therefore, null hypothesis accepted for both years, meaning that there is no significant relationship between OUTDIR and the likelihood of corporate fraud. Holding many directorships, one could argue, increases the directors' knowledge and experience, which in turn improves their abilities and expertise. On the other hand, holding many directorships could become a problem as the director may struggle to concentrate on the matters at hand. Analysing and monitoring financial activities and reports is not easy and requires a lot of time. The high percentage of directors holding many directorships in this study (for both groups) was not beneficial to company governance as it did not reduce the likelihood of corporate fraud. The regulations do not impose any specific restrictions, but do require directors to disclose their multiple directorships. Further investigation could be carried out to determine how many is too many when it comes to effective governance. This could help regulators formulate more effective requirements for Malaysian companies.

Institutional shareholding (BLOCK) was the strongest significant predictor in the logistic regression analysis. BLOCK was significant at the $1 \%$ level, with a $p$ value of 0.009 . There was a negative $B$ value of -0.078 , which means that an increase in the percentage of institutional shareholding reduces the likelihood of fraud occurrences. The odds ratio (0.925) was less than 1 , indicating that for every additional percentage of institutional shareholdings, fraud is less likely to occur, controlling other factors in the model. Institutional shareholding (BLOCK) was another significant predictor in the regression model, but not in the univariate analysis. BLOCK was significant at the $1 \%$ level, with a $p$ 
value of 0.003 . There was a negative $B$ value of -0.093 , meaning an increase in the percentage of institutional shareholdings which reduces the likelihood of fraud occurrences. The odds ratio (0.911) was less than 1, indicating that for every additional $1 \%$ of institutional shareholdings, it will be less likely for companies to commit fraud. Therefore, null hypothesis is rejected for both years as this study shows that there is significant relationship between BLOCK and the likelihood of corporate fraud. Having a higher percentage of institutional shareholding, subjects companies to more detailed scrutiny by institutions thus, increasing the effectiveness of institutional shareholdings. These institutions have the resources to monitor the companies' activities and reporting, which individual shareholders do not have. Institutions are more rigorous in monitoring, as they themselves have to answer to their investors if anything goes wrong.

\section{Conclusion}

This study shows that certain corporate governance characteristics that should be effective in curbing corporate fraud are in fact not effective in Malaysia, namely: the independence of the board of directors. Therefore, more emphasis should be put on improving corporate governance structures. The role of institutional shareholders should be highlighted and they should play a more important role in their company's governance. Multiple directorships of board members seem to be beneficial to companies' governance in Malaysia. The contribution of knowledge gained from holding multiple directorships could increase director expertise apart from formal training. A more in-depth analysis on the role of institutional theory in the development on corporate governance is valuable for the development of governance policy.

The limitation of director's tenure to nine years is appropriate as knowledge and experience is important, apart from formal education and training. This is consistent with the effectiveness of having multiple directorships that reduces the likelihood of corporate fraud occurrences. This shows that formal education and training is not enough which perhaps could be suggested to the education sector to increase students understanding in financial reporting. The multiracial factor that brought with it culture and values into how business is managed could be one of the reasons that directors need as experience and knowledge to help them carry out their duties effectively.

The effectiveness of corporate governance in fraud deterrence is quite complex and not easy to quantify. Effective corporate governance will result in better (if not effective) monitoring and controlling over management activities and corporate reporting. The results suggested that many of the strong corporate governance characteristics put forward were not able to detect corporate fraud occurrences. The findings suggested that the development of corporate governance should be tailored to the company's unique needs and environment, and should not just focus on meeting the regulatory requirements. In particular, board and audit committee members should be more effective in assessing and evaluating financial reports. This study also suggests that other corporate governance characteristics should be investigated to determine their relationships with the likelihood of corporate fraud. Companies' published information, to a certain extent, is useful provided that users exercise caution in digesting it, and know what to look for and how to interpret the information. Some of the variables that were found to be significant in this study could provide guidance for users in assessing companies' published information and performance.

The empirical results of this study only represent one of many areas of corporate governance structures. Future research should consider a broader investigation on governance attributes and how they relate to the likelihood of corporate fraud. Future research should also consider analyzing corporate fraud using a case study approach to give a more in-depth understanding of this issue. This could offer a better view on company governance. Apart from adopting a positivist paradigm (as this study did), future researchers could analyze or study this issue from a more critical perspective or from an interpretative view. This could produce more in-depth explanations and understanding of the problems of governance and fraud.

\section{Acknowledgment}

The authors would like to express their gratitude to Universiti Teknologi MARA for facilitating this research project.

\section{References}

Abbott, L. J., Park, Y., \& Parker, S. (2000). The effects of audit committee activity and independence on corporate fraud. Managerial Finance, 26(11), 55-67. https://doi.org/10.1108/03074350010766990

Abbott, L. J., Parker, S., \& Peters, G. F. (2004). Audit committee characteristics and restatements. Auditing: A Journal of Practice and Theory, 23(1), 19. https://doi.org/10.2308/aud.2004.23.1.69

Abdul Rahman, R., \& Mohamed Ali, F. H. (2008). Board, audit committee, culture and earnings management: Malaysian evidence. Managerial Auditing Journal, 21(7), 783. https://doi.org/10.1108/02686900610680549

Abdullah, S. N., Yusof, N. Z. M., \& Nor, M. N. M. (2010). Financial restatements and corporate governance among 
Malaysian listed companies. Managerial Auditing Journal, 25(6), 526-552. https://doi.org/10.1108/02686901011054854

Ahrens, T., Filatotchev, I., \& Thomsen, S. (2011). The research frontier in corporate governance. Journal of Management and Governance on Emerging Issues in Management and Governance, 15, 311-325. https://doi.org/10.1007/s10997-009-9115-8

AICPA. (1993). The Public Oversight Board's special report: Issues confronting the accounting profession. Stanford, CT: AICPA.

Anwar, Z. (2006). The role of the internal audit functions in good governance. Keynote address at the Institute of Internal Auditors Malaysia, 2006 National Conference, Malaysia. Retrieved 20 December 2008, from www.sc.com.my

Baysinger, B. D., \& Hoskisson, R. E. (1990). The composition of boards of directors: Performance effects of changes in board composition. Academy of Management Review, 71(1), 71-87.

Beasley, M. S. (1996). An empirical analysis of the relation between the board of director composition and financial statement fraud. The Accounting Review, 71(4), 443-465.

Beasley, M. S., Carcello, J. V., \& Hermanson, D. R. (2000). Preventing fraudulent financial reporting. The CPA Journal, 70(12), 14. https://doi.org/10.2308/acch.2000.14.4.441

Beasley, M. S., Carcello, J. V., Hermanson, D. R., \& Lapides, P. D. (2000). Fraudulent financial reporting: Consideration of industry traits and corporate governance mechanisms. Accounting Horizons, 14(4), 441. https://doi.org/10.2308/acch.2000.14.4.441

Bédard, J., Chtourou, S. M., \& Courteau, L. (2004). The effect of audit committee expertise, independence, and activity on aggressive earnings management. Auditing, 23(2), 13. https://doi.org/10.2308/aud.2004.23.2.13

Bell, T. B., \& Carcello, J. V. (2000). A decision aid for assessing the likelihood of fraudulent financial reporting. Auditing, 19(1), 169. https://doi.org/10.2308/aud.2000.19.1.169

Bliss, M. A., Gul, F. A., \& Majid, A. (2011, December). Do political connections affect the role of independent audit committees and CEO duality? Some evidence from Malaysian audit pricing. Journal of Contemporary Accounting \& Economics, 7(2), 82-89. https://doi.org/10.1016/j.jcae.2011.10.002

Borokhovich, K. A., Parrino, R., \& Trapani, T. (1996). Outside directors and CEO selection. Journal of Quantitative Analysis, 31(3), 19. https://doi.org/10.2307/2331395

Bradbury, M., Mak, Y., \& Tan, S. (2006). Board characteristics, audit committee characteristics and abnormal accruals. Pacific Accounting Review, 18(2), 22. https://doi.org/10.1108/01140580610732813

Burns, J. (2003). Corporate governance (a special report): Everything you wanted to know about corporate governance... But didn't know to ask. Wall Street Journal, R.6. Retrieved from http://ezproxy.lincoln.ac.nz/login?url=http://proquest.umi.com/pqdweb?did=431090931\&Fmt=7\&clientId=189 $63 \& \mathrm{RQT}=309 \& \mathrm{VName}=\mathrm{PQD}$

Bushee, B. J. (2000). Do institutional investors prefer near-term earnings over long-run value?. Working Paper, University of Pennsylvania. https://doi.org/10.2139/ssrn.161739

Carcello, J. V., \& Nagy, A. L. (2004). Client size, auditor specialization and fraudulent financial reporting. Managerial Auditing Journal, 19(5), 651. https://doi.org/10.1108/02686900410537775

Chen, G., Firth, M., Gao, D. N., \& Rui, O. M. (2006). Ownership structure, corporate governance and fraud: Evidence from China. Journal of Corporate Finance, 12, 424-448. https://doi.org/10.1016/j.jcorpfin.2005.09.002

Claessens, S., Djankov, S., \& Lang, L. H. P. (2000). The separation of ownership and control in East Asian corporations. Journal of Financial Economics, $58(1-2), \quad 81-112$. https://doi.org/10.1016/S0304-405X(00)00067-2

Cullinan, C. P., \& Sutton, S. G. (2002). Defrauding the public interest: A critical examination of reengineered audit processes and the likelihood of detecting fraud. Critical Perspectives on Accounting, 13(3), 297-310. https://doi.org/10.1006/cpac.2001.0527

Dey, A., Engel, E., \& Liu, X. (2011), CEO and board chair roles: To split or not to split?. Journal of Corporate Finance, 17(5), 1595-1618. https://doi.org/10.1016/j.jcorpfin.2011.09.001

Fama, E. F. (1980). Agency problems and the theory of the firm. The Journal of Political Economy, 88(2), 288-307. 
https://doi.org/10.1086/260866

Fama, E. F., \& Jensen, M. C. (1983). Separation of ownership and control. Journal of Law and Economics, 26(2), 301-325. https://doi.org/10.1086/467037

Farber, D. B. (2005). Restoring trust after fraud: Does corporate governance matter?. The Accounting Review, 80(2), 539-561. https://doi.org/10.2308/accr.2005.80.2.539

Ferris, S. P., Jagannathan, M., \& Pritchard, A. C. (2003). Too busy to mind the business? Monitoring by directors with multiple board appointments. The Journal of Finance, 58(3), 1087-1111. https://doi.org/10.1111/1540-6261.00559

Foulidi, X., Papakitsos, E. C., Papakitsos, E. C., Vamvakeros, X., \& Dimou, I. (2018). Teachers of Secondary Education and Professional Stress with Students Performance: A Geographical Case Study. Humanities and Social Sciences Letters, 6(3), 121-129. https://doi.org/10.18488/journal.73.2018.63.121.129

Garfield, A. (2018). Uprooted in Art: Contemporary Considerations of Refugee Art. International Journal of Social Sciences Perspectives, 2(2), 101-111. https://doi.org/10.33094/7.2017.2018.22.101.111

Georgantopoulos, A. G., Poutos, E. I., \& Eriotis, N. (2018). Recent Developments and Trends in Accounting Information Systems. Journal of Accounting, Business and Finance Research, 3(1), 1-9.

Gérard, T., \& Oumbé, T. (2018). Trade Policy And Democracy For Development In Central African Countries. Journal of Empirical Studies, 5(1), 55-66. https://doi.org/10.18488/journal.66.2018.51.55.66

Ghorashi, F., \& Darabi, R. (2017). Compare Value at Risk and Return of Assets Portfolio Stock, Gold, REIT, US \& Iran Market Indices. Asian Journal of Economic Modelling, 5(1), 44-48. https://doi.org/10.18488/journal.8/2017.5.1/8.1.44.48

Goral, R., \& Akgoz, E. (2017). Tourism Price Competition Index for National Destinations. Journal of Tourism Management Research, 4(1), 17-29. https://doi.org/10.18488/journal.31.2017.41.17.29

Grove, H., \& Basilico, E. (2008). Fraudulent financial reporting detection: Key ratios plus corporate governance factors. International Studies of Management \& Organization, 38(3), 10. https://doi.org/10.2753/IMO0020-8825380301

Grove, H., \& Cook, T. (2004). Lessons for auditors: Quantitative and qualitative red flags. Journal of Forensic Accounting, 5(1), 131.

Haniffa, R. M., \& Cooke, T. E. (2002). Culture, corporate governance and disclosure in Malaysian corporations. Abacus, 38(3), 317. https://doi.org/10.1111/1467-6281.00112

Haniffa, R., \& Hudaib, M. (2006). Corporate governance structure and performance of Malaysian listed companies. Journal of Business Finance \& Accounting, 33(7-8), 1034-1062.

Hashim, H. A., \& Devi, S. S. (2008). Board independence, expertise and earnings quality: Malaysian evidence. Paper presented at the Accounting and Finance Association of Australia and New Zealand.

Hasnan, S., Abdul Rahman, R., \& Mahenthrian, S. (2008). Management predisposition, motive, opportunity, and earnings management for fraudulent financial reporting in Malaysia. SSRN eLibrary.

He, L., Labelle, R., Piot, C., \& Thornton, D. B. (2009). Board monitoring, audit committee effectiveness and financial reporting quality: Review and synthesis of empirical evidence. Journal of Forensic and Investigative Accounting, 1(2), 42.

Hermalin, B. E. (2005). Trends in corporate governance. The Journal of Finance, 60(5), 2351-2384.

Hermalin, B. E., \& Weisbach, M. S. (1988). The determinants of board composition. The RAND Journal of Economics, 19(4), 589-606. https://doi.org/10.2307/2555459

Hill, C. W. L., \& Phan, P. (1991). CEO tenure as a determinant of CEO pay. Academy of Management Journal, 34(3), 707. https://doi.org/10.2307/256413

Hofstede, G. (1980). Culture's consequences: International differences in work related values. Newbury Park, CA: Sage Publications Inc.

Jensen, M. C. (1986). Agency cost of free cash flow and the performance of bank initial public offerings. Journal of Banking and Finance, 23, 1277-1301. https://doi.org/10.1016/S0378-4266(99)00014-X

Jensen, M. C. (1993). The modern industrial revolution, exit, and the failure of internal control systems. The Journal of Finance, 48(3), 831-880. https://doi.org/10.1111/j.1540-6261.1993.tb04022.x 
Kim K. H., Al-Shammari, H. A., \& Kim, B. (2009). CEO duality leadership and corporate diversification behaviour. Journal of Business Research, 62(11), 1173-1180. https://doi.org/10.1016/j.jbusres.2008.10.017

Li, J., \& Ang, J. (2000). Quantity versus quality of director's time: The effectiveness of directors and number of outside directorships. Managerial Finance, 26(10), 1-21. https://doi.org/10.1108/03074350010766909

Lipton, M., \& Lorsch, J. W. (1992). A modest proposal for improved corporate governance. The Business Lawyer, $48(1), 59$.

Mohd Salleh, S., \& Othman, R. (2016). Board of director's attributes as deterrence to corporate fraud. Procedia Economics and Finance, 35, 82-91. https://doi.org/10.1016/S2212-5671(16)00012-5

Mulgrew, M., \& Forker, J. (2006). Independent non-executive directors and earnings management in the UK. The Irish Accounting Review, 13(2), 35-62.

Owens-Jackson, L. A., Robinson, D., \& Shelton, S. W. (2009). The association between audit committee characteristics, the contracting process and fraudulent financial reporting. American Journal of Business, 24(1), 57-65. https://doi.org/10.1108/19355181200900005

Persons, O. S. (2005). The relation between the new corporate governance rules and the likelihood of financial statement fraud. Review of Accounting \& Finance, 4(2), 125. https://doi.org/10.1108/eb043426

Petra, S. T. (2005). Do outside independent directors strengthen corporate boards?. Corporate Governance, 5(1), 55-64. https://doi.org/10.1108/14720700510583476

PwC's. (2018). Global Economic Crime and Fraud Survey. Pulling fraud out of the shadows, Pricewaterhousecoopers.

Ramaswary, V. (2005). Corporate governance and the forensic accountant. The CPA Journal, 75(3), 68.

Rezaee, Z. (2005). Causes, consequences, and deterrence of financial statement fraud. Critical Perspectives on Accounting, 16(3), 277-298. https://doi.org/10.1016/S1045-2354(03)00072-8

Riahi-Belkaoui, A., \& Picur, R. D. (2000). Understanding fraud in the accounting environment. Managerial Finance, 26(11), 33-41. https://doi.org/10.1108/03074350010766972

Saksena, P. (2003). The relationship between corporate governance and management fraud: An empirical analysis. Academy of Accounting and Financial Studies Journal, 7(3), 21.

Salleh, Z., Stewart, J., \& Manson, S. (2016). The board composition and ethnicity on audit quality: Evidence from Malaysian companies. Managerial Accounting Review, 5(2), 61-83.

Sarkar, J., \& Sarkar, S. (2009). Multiple board appointments and firm performance in emerging economies: Evidence from India. Pacific-Basin Finance Journal, 17(2), 271-293. https://doi.org/10.1016/j.pacfin.2008.02.002

Schnake, M. E., \& Williams, R. J. (2008). Multiple directorships and corporate misconduct: The moderating influences of board size and outside directors. Journal of Business Strategies, 25(1), 1.

Sharma, V. D., \& Iselin, E. R. (2012). The association between audit committee multiple-directorships, tenure, and financial misstatements. Auditing: A Journal of Practice \& Theory, 31(3), 149-175.

Smaili, N., \& Labelle, R. (2009). Preventing and detecting accounting irregularities: The role of corporate governance. SSRN eLibrary. https://doi.org/10.2139/ssrn.1324143

Tanyi, P. N., \& Smith, D. B. (2014). Busyness, expertise, and financial reporting quality of audit committee chairs and financial experts. Auditing: A Journal of Practice \& Theory, 34(2), 59-89.

Treadway Commission. (1999). Fraud financial reporting 1987-1997, an analysis of U.S. public companies. New York, NY: Committee of Sponsoring Organizations of the Treadway Commission (COSO).

Uzun, H., Szewczyk, S. H., \& Varma, R. (2004). Board composition and corporate fraud. Financial Analysts Journal, 60(3), 33. https://doi.org/10.2469/faj.v60.n3.2619

Xie, B., Davidson, W. N., \& Dadalt, P. J. (2003). Earnings management and corporate governance: The role of the board and the audit committee. Journal of Corporate Finance, 9, 295-316.

Yatim, P., Kent, P., \& Clarkson, P. (2006). Governance structures, ethnicity, and audit fees of Malaysian listed firms. Managerial Auditing Journal, 21(7), 757-782. https://doi.org/10.1108/02686900610680530

Yermack, D. (1996). Higher market valuation of companies with a small board of directors. Journal of Financial Economics, 40(2), 185-211. https://doi.org/10.1016/0304-405X(95)00844-5 